\title{
Diseño y prestaciones de morteros de albañilería elaborados con áridos reciclados procedentes de escombro de hormigón
}

\section{Design and performance of masonry mortars made with recycled concrete aggregates}

\author{
$\underline{\operatorname{I.~} \operatorname{Vegas}}^{(*)}$, I. Azkarate ${ }^{(* *)}$, A. Juarrero(***), M. Frías $(* * * *)$
}

Recepción/Received: 11-X-07

Aceptación/Accepted: 28-I-08

Publicado online/Online publishing: 06-VII-09

RESUMEN

El presente trabajo presenta y discute las condiciones de viabilidad técnica para la utilización de la fracción fina de áridos reciclados, procedentes de escombro de hormigón, en la fabricación de morteros de albañilería utilizando cemento como conglomerante.

Inicialmente, se estudian las características químicas y físico-mecánicas de los áridos reciclados finos procedentes de hormigón seleccionado. Se concluye que las características limitantes del árido reciclado para su uso en morteros de albañilería resultan ser la alta absorción y el elevado contenido en sulfatos, en comparación con las arenas naturales de naturaleza caliza. De forma análoga a lo recomendado en el hormigón estructural, se apunta hacia la utilización de mezclas de áridos reciclados y naturales en la fabricación de morteros de albañilería.

Del estudio de dosificaciones y caracterización de morteros, elaborados con áridos reciclados de hormigón, se establece que los morteros de albañilería base cemento pueden incorporar un $25 \%$ como máximo de árido reciclado sin evidenciar pérdidas significativas de prestaciones. $Y$, no requiere de nuevos aditivos ni de una mayor cantidad de cemento.

Palabras clave: árido reciclado de hormigón, mortero de albañilería, prestaciones mecánicas, durabilidad.

\section{SUMMARY}

The present paper discusses the technical feasibility of using the fine fraction of recycled aggregate from concrete rubble to manufacture cement mortar and possible conditions.

An initial study of the chemical and physical-mechanical characteristics of fines recycled from selected concrete showed that their high absorptivity and high sulfate content compared to natural limestone sands were the limiting factors to their in masonry mortars. As in the case of structural concrete, a blend of recycled and natural aggregate would appear to be suitable for masonry mortars.

A study of the mix proportions and characteristics of mortars made with recycled concrete aggregate showed that up to $25 \%$ recycled aggregate can be used in cement-based masonry mortars with no significant decline in performance and no new admixtures or higher cement content requires.

Keywords: recycled-concrete aggregate, masonry mortar, mechanical performance, durability.

\footnotetext{
(*) LABEIN-Tecnalia (Derio, España).

(**) MORTEROS Y REVOCOS BIKAIN, S.A. (Mañaria-Bizkaia, España).

(***) VOLBAS, S.A. (Bilbao, España).

$(* * * *)$ Instituto de Ciencias de la Construcción Eduardo Torroja (IETcc-CSIC) (Madrid, España).
} 


\section{INTRODUCCIÓN}

En Europa, la utilización de los áridos reciclados procedentes de los residuos de construcción y demolición (RCD) está orientada, fundamentalmente, hacia la construcción de secciones de carreteras, si bien en determinados países dichos áridos se utilizan también en la fabricación de hormigón estructural. La normativa holandesa NEN 6720:1995 describe y permite su utilización con una sustitución máxima de un $20 \%$ (1).

En España, la nueva Instrucción de Hormigón Estructural (EHE-08) regula la utilización de este tipo de material granular. Basado en los trabajos realizados por el Grupo de Trabajo 2/5 "Hormigón Reciclado" dentro de la Comisión 2 perteneciente a la Asociación Científico-Técnica de Hormigón Estructural (ACHE), se permite única y exclusivamente la utilización de la fracción gruesa (tamaño superior a $4 \mathrm{~mm}$ ), sustituyendo un $20 \%$ (en peso) de árido natural por árido reciclado de hormigón convencional. No se puede utilizar el árido fino reciclado, debido a su alta capacidad de absorción y a una mayor probabilidad de contener impurezas $(2,3)$.

Bajo este contexto, se plantea explorar otras alternativas constructivas que doten de un mayor valor añadido a la salida comercial de la fracción fina reciclada. En este sentido, la elaboración de morteros de albañilería y revoco constituyen, desde un punto de vista apriorístico, potenciales aplicaciones de aprovechamiento de la fracción fina de hormigón reciclado. A diferencia del hormigón estructural, la fabricación de morteros no está sujeta a normativa estructural lo que comporta un mayor número de medidas conservadoras en cuanto a diseño y utilización de materiales.

Se encuentran pocas referencias científicas sobre la utilización de áridos reciclados en morteros. Winkler et al. (4) y Sánchez de Rojas et al. (5) analizaron el efecto de introducir polvo reciclado de elementos cerámicos "puros" en la formación y estabilización de las fases hidratadas. Los autores partieron de algunas teorías sobre la puzolanicidad del polvo cerámico. Se evidenció un aumento de la trabajabilidad en la fabricación de los morteros con un $20 \%$ de polvo cerámico de material cocido a alta y media temperaturas. Asimismo, se constató una mejora en el desarrollo de resistencias con polvo cerámico de baja temperatura. Mesbah et al. (6) estudiaron la influencia de la arena reciclada en la retracción del mortero durante diferentes fases de curado. Después de 600 días de curado, se evidenció una gran diferencia de retracción entre morteros con arena reciclada $(2.010 \mu \mathrm{m} / \mathrm{m})$ y morteros con arena natural $(1.060 \mu \mathrm{m} / \mathrm{m})$, como consecuencia de la alta porosidad y absorción de los áridos reciclados finos. Al objeto de mitigar los efectos de fisuración

\section{INTRODUCTION}

In Europe, recycled aggregate from construction and demolition waste (C\&D waste or CDW) is primarily used for building roads, although in certain countries it is also used in the manufacture of structural concrete. Dutch standard NEN 6720:1995 describes its use and allows replacement of up to $20 \%$ of the natural aggregate with such waste (1).

In Spain, the new Structural Concrete Code (EHE-08) regulates the use of this type of granular material. Further to the work conducted by ACHE (Asociación Científico-Técnica del Hormigón Estructural: scientific and technical association for structural concrete) Committee Two's Working Group 2/5 on Recycled Concrete, only the coarse fraction (over $4 \mathrm{~mm}$ ) is allowed, and the maximum replacement percentage is $20 \%$ (by weight). The use of recycled fine aggregate is not permitted because of its high absorption and larger proportion of impurities $(2,3)$.

One suggestion that has been put forward in this context is to explore other building alternatives that would afford recycled fines greater market value. The manufacture of masonry mortars and plaster would, at first glance, seem to be potential applications where the fine fraction of recycled concrete could be used. Unlike structural concrete, the manufacture of mortars is not subject to the conservative design and material use provisions of structural regulations.

There are few scientific references to the use of recycled aggregate in mortars. Winkler et al. (4) and Sánchez de Rojas et al. (5) analyzed the effect of using recycled powder from "pure" ceramic products in the formation and stabilization of the hydrated phases. Their point of departure was a series of assumptions around ceramic powder pozzolanicity. Mortars containing $20 \%$ ceramic powder from material fired at high and medium temperatures exhibited greater workability than the standard material. The inclusion of powder from low-temperature ceramics enhanced strength development. Mesbah et al (6) studied the influence of recycled sand on mortar shrinkage during curing. After 600 days, a considerable difference in shrinkage was observed between mortars with recycled sand $(2010 \mu \mathrm{m} / \mathrm{m})$ and mortars with natural sand $(1060 \mu \mathrm{m} / \mathrm{m})$, as a result of the high porosity and absorptivity of the recycled fines. Aiming to mitigate the effects of shrinkage cracking in mortar, Mesbah studied and modelled the impact of combining 
por retracción del mortero, Mesbah investigó y modelizó la incidencia de combinar fibras metálicas o de propileno con arena reciclada, concluyendo que un contenido de fibra mayor de $0,25 \%$ en peso retrasa la aparición de fisuración, toda vez que reduce significativamente la anchura de las fisuras inducidas. Corinaldesi et al. (7) analizaron algunas propiedades mecánicas de los morteros elaborados con arena reciclada de residuos de demoliciones, reforzados con diferentes tipos de fibras, concluyendo que dichos morteros presentan excelente resistencia a la adherencia con ladrillos. Se han de destacar, asimismo, las contribuciones realizadas por Selmo y Miranda (8-10), dirigidas a analizar la influencia de mezclas de áridos reciclados de diferente naturaleza, sobre algunas de las propiedades del mortero fresco y endurecido.

El trabajo que aquí se presenta recoge parte de los resultados de un proyecto de investigación más amplio dirigido a establecer las condiciones de viabilidad (técnica, medioambiental y económica) de utilizar áridos reciclados en morteros de albañilería (utilizando cemento como conglomerante) y rehabilitación (utilizando cal como conglomerante). Los resultados presentados en este trabajo constituyen una contribución respecto a los trabajos ya publicados, puesto que se profundiza en el diseño de morteros y en la caracterización de los morteros elaborados con áridos reciclados.

\section{MATERIALES Y PARTE EXPERIMENTAL}

\subsection{Materiales}

Árido de reciclado. El escombro de hormigón seleccionado (Figura 1) se procesó en la planta de tratamiento de RCD hasta obtener un árido reciclado de tamaño inferior a 5 $\mathrm{mm}$ (Figura 2). Se procesaron seis muestras de hormigón

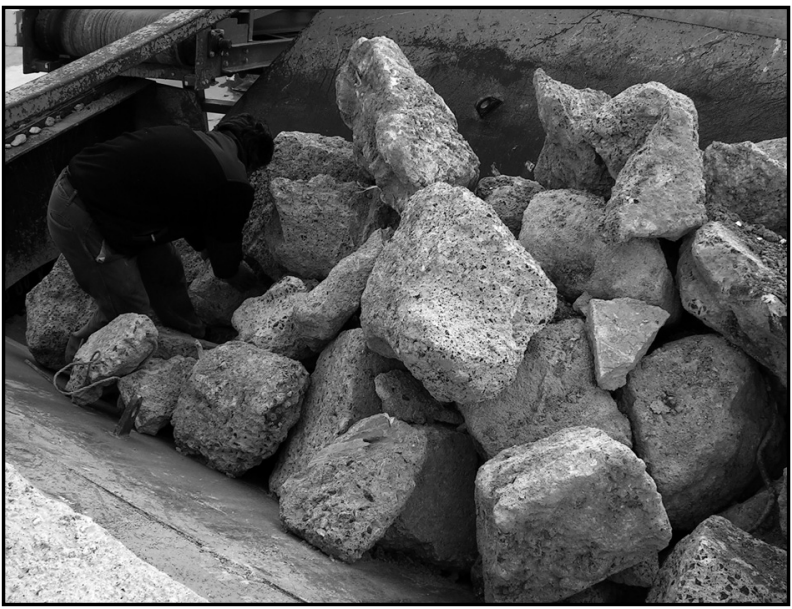

Figura 1. Escombro de hormigón. Figure 1. Concrete waste. steel or polypropylene fibres with recycled sand and concluded that a fibre content of over $0.25 \%$ by weight delayed the appearance of cracking, as it significantly reduced crack width. Corinaldesi et al. (7) analyzed certain mechanical properties of mortars made with sand recycled from demolition waste, reinforced with different types of fibres. They concluded that those mortars revealed an excellent bonding strength when applying to bricks. Selmo and Miranda (8-10), in turn, contributed to the analysis of the effect of mixtures of different types of recycled aggregate on some of the properties of fresh and hardened mortar.

This paper reports on part of the results of a broader research project intended to establish the technical, environmental and economic feasibility of using recycled aggregate in cement-based masonry mortar and limebased rehabilitation mortar. The findings contribute to the published acquis, insofar as they advance more deeply into mortar design and the characterization of mortars made with recycled aggregate.

\section{MATERIALS AND EXPERIMENTAL}

\subsection{Materials}

Recycled aggregate. The selected concrete rubble (Figure 1) was processed at the $C \& D$ waste treatment plant to obtain a recycled aggregate with a particle size of under $5 \mathrm{~mm}$ (Figure 2). Six samples of the selected

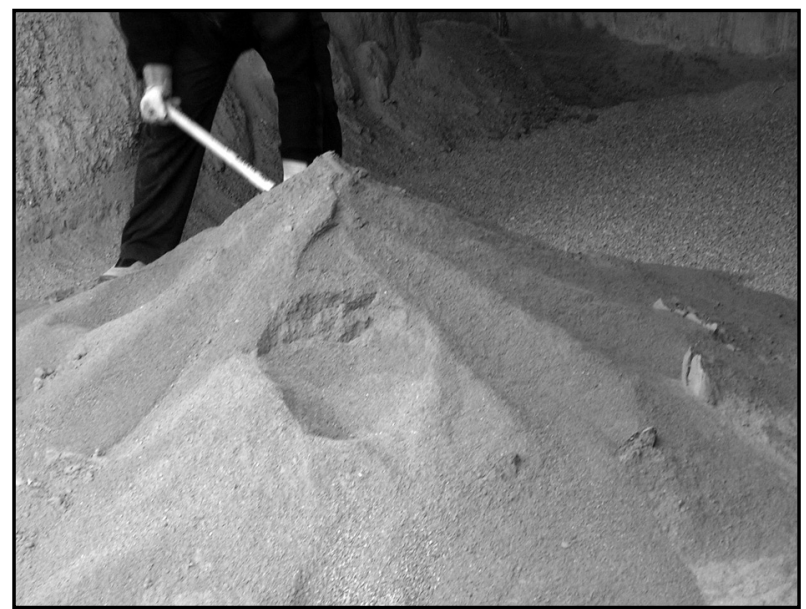

Figura 2. Toma de muestras serie FRH. Figure 2. Sampling: Serie FRH. 
seleccionado que fueron recogidas en tiempos diferentes. Los áridos reciclados resultantes se identificaron como FRH-i (con un valor de i comprendido entre 1 y 6). Previamente al proceso de trituración y molienda, se procedió a la extracción de testigos cilíndricos $(\varnothing=75 \mathrm{~mm})$ de hormigón para la realización de ensayos de compresión, al objeto de conocer la calidad del material de partida. Los resultados obtenidos en el ensayo de compresión para los testigos extraídos se recogen en la Tabla 1. A la vista de estos resultados, puede concluirse que el hormigón que llega a la planta es, en general, de baja calidad, con resistencias a compresión que en la mayoría de los casos no superan los $20 \mathrm{MPa}$ (se ha obtenido una media de 21,5 MPa tras la rotura de nueve testigos). concrete, collected at different times, were processed. The resulting recycled aggregates were identified as FRH-i (with i ranging from 1 to 6). Cylindrical specimens $(\varnothing=75 \mathrm{~mm}$ ) were removed from the concrete prior to the crushing and grinding process for compression testing to determine the quality of the initial material. The findings are shown in Table 1. These results infer that the concrete delivered to the plant was of generally low quality, with compressive strengths below $20 \mathrm{MPa}$ in most cases (an average of $21.5 \mathrm{MPa}$ was obtained from nine specimens tested to failure).

Tabla 1 / Table 1

Resistencia a compresión de testigos de hormigón de 75 mm de diámetro. Compressive strength of cylindrical concrete specimens ( $75 \mathrm{~mm}$ of diameter).

\begin{tabular}{|c|c|}
\hline Muestra / Sample & $\begin{array}{c}\text { Resistencia a compresión / } \\
\text { Compressive strength (MPa) }\end{array}$ \\
\hline FRH-1 (1) & 19.3 \\
\hline FRH-1 (2) & 40.3 \\
\hline FRH-2 (1) & 19.8 \\
\hline FRH -2 (2) & 10.8 \\
\hline FRH-3 (1) & 30.6 \\
\hline FRH-3 (2) & 16.6 \\
\hline FRH-4 (1) & 22.5 \\
\hline FRH-5 (1) & 16.2 \\
\hline FRH-6 (1) & 17.3 \\
\hline Media / Average & 21.5 \\
\hline
\end{tabular}

Conglomerante. En cuanto al tipo de conglomerante, se utilizó un cemento CEM II/B-M (V-S-LL) 42,5 R. La Tabla 2 presenta algunas características de este cemento.
Binder. The type of binder used was CEM II/B-M(V-S-LL) $42.5 R$ cement. Table 2 gives the characteristics of this cement.

Tabla 2 / Table 2

Características del CEM II/B-M(V-S-LL) 42,5 R.

Characteristics of CEM II/B-M(V-S-LL) 42,5 R.

\begin{tabular}{|c|c|}
\hline \multicolumn{2}{|c|}{ Características químicas / Chemical characteristics } \\
\hline $\mathrm{SiO}_{2}$ (\%) & 22.43 \\
\hline $\mathrm{CaO}^{(\%)}$ & 56.40 \\
\hline $\mathrm{Al}_{2} \mathrm{O}_{3}(\%)$ & 6.83 \\
\hline $\mathrm{Fe}_{2} \mathrm{O}_{3}(\%)$ & 2.82 \\
\hline $\mathrm{MgO}(\%)$ & 2.11 \\
\hline $\mathrm{SO}_{3}(\%)$ & 3.04 \\
\hline $\mathrm{PF} / \mathrm{LOI}(\%)$ & 4.53 \\
\hline Características físicas / Physical characteristics \\
\hline Densidad real / Density (g/cm $\left.{ }^{3}\right)$ & 3.04 \\
\hline Superficie específica Blaine / Blaine Specific area (cm²/g) & 3693 \\
\hline Inicio de fraguado / Inicial set (min) & 190 \\
\hline Fin de fraguado / Final set (min) & 273 \\
\hline \multicolumn{2}{|c|}{ Características mecánicas / Mechanical characteristics } \\
\hline Compresión a 2 días / Compression strength at 2 days (MPa) & 31.7 \\
\hline Compresión a 28 días / Compression strength at 28 days MPa) & 58.1 \\
\hline \multicolumn{2}{|c|}{} \\
\hline \multicolumn{2}{|c|}{} \\
\hline \multicolumn{2}{|c|}{} \\
\hline
\end{tabular}




\subsection{Caracterización y metodología de ensayo}

Las muestras de árido reciclado se caracterizaron de acuerdo a la UNE-EN 13139: "Áridos para morteros" (11). Las propiedades analizadas, así como su correspondiente norma, se recogen en la Tabla 3. Se utilizó un árido natural calizo para servir como material granular de referencia.

\subsection{Characterization and test methodology}

The recycled aggregate samples were characterized in accordance with Spanish and European standard UNEEN 13139: "Aggregates for mortar" (11). The properties analyzed and respective standards are shown in Table 3. A natural limestone aggregate was used as the reference granular material.

Tabla 3 / Table 3

Caracterización de los áridos reciclados para morteros.

Characterization of recycled aggregates for mortars.

\begin{tabular}{|c|c|}
\hline Característica / Characteristic & Norma utilizada / Standard \\
\hline Granulometría y porcentaje de finos / Particle size distribution. Assessment of fines (\%) & UNE EN 933-1/98 \\
\hline Equivalente de arena / Sand equivalent $(\%)$ & UNE EN 933-8/00 \\
\hline Azul de metileno / Methylene blue test $(\mathrm{gr} / \mathrm{kg}$ fracción $0,2 \mathrm{~mm})$ & UNE EN 933-9/99 \\
\hline Densidad real de la muestra seca / Dry sample density $\left(\mathrm{g} / \mathrm{cm}^{3}\right)$ & UNE $1097-6 / 00$ \\
\hline Coeficiente de absorción de agua / Water absorption coefficient $(\%)$ & UNE 1097-6/00 \\
\hline Coeficiente de friabilidad / Friability coefficient $(\%)$ & UNE $83115 / 89$ \\
\hline Compuestos de azufre totales / Total sulphurs $\left(\% \mathrm{SO}_{3}\right)$ & UNE EN 1744-1-99 \\
\hline Sulfatos solubles en ácido / Acid soluble sulphates $\left(\% \mathrm{SO}_{3}\right)$ & UNE EN 1744-1-99 \\
\hline Cloruros solubles en agua / Water soluble chlorides $(\% \mathrm{Cl})$ & UNE EN 1744-1-99 \\
\hline
\end{tabular}

La caracterización de las propiedades físico-mecánicas, reológicas e hídricas de los morteros en estado fresco y endurecido se realizó de acuerdo a la normativa vigente (serie UNE-EN 1015).

El análisis mineralógico se llevó a cabo mediante la técnica de difracción de rayos X (DRX). La medida difractométrica se efectuó con un difractómetro Philips X'Pert Pro MPD pw3040/60, equipado con tubo cerámico de cobre. Las condiciones instrumentales de la medida han sido: barrido continuo durante una hora de 2 a $75^{\circ} 2 \theta$, con una tensión del generador de 40kV y 40 mA. Para su adecuado procesamiento, la muestra analizada fue molida y homogeneizada manualmente en un mortero de ágata.

\subsection{Dosificaciones}

A partir del conocimiento obtenido en la caracterización de las diferentes muestras de áridos reciclados, se procedió al estudio de dosificaciones y propiedades de morteros de albañilería con áridos reciclados procedentes del escombro de hormigón. Se trabajó con la muestra de árido reciclado denominada FRH-6 al considerarla lo suficientemente representativa del conjunto analizado y exenta de cualquier tipo de patología.

En laboratorio, el árido reciclado obtenido en planta $(<5 \mathrm{~mm}$ ) se tamizó por debajo de $2 \mathrm{~mm}$ al objeto de ajustarse a los requerimientos de tamaño máximo de arena utilizado en la empresa de morteros. La curva granulométrica se ilustra en la Figura 3.
The physical, mechanical, rheological and moisture properties of the fresh and hardened mortars were characterized in accordance with existing standards (UNE-EN 1015 series).

$X$-ray diffraction (XRD) was used to perform the mineral analysis. XRD readings were taken with a Philips $X^{\prime} P e r t$ Pro MPD pw3040/60 diffractometer equipped with a ceramic copper tube. The instrumental settings were: continuous scan for one hour at $2 \theta=2-75^{\circ}$, with a generator voltage of $40 \mathrm{kV}$ and a current of $40 \mathrm{~mA}$. To ensure proper processing, the sample analyzed was manually ground and blended in an agate mortar.

\subsection{Mix proportions}

The information gathered from the characterization tests served as a basis for studying the mix proportions and properties of masonry mortars containing recycled concrete aggregate. The sample marked FRH- 6 was chosen for the trails, for it was regarded to be representative enough of all the samples analyzed and free from any type of pathology.

In the laboratory, the recycled aggregate processed at the plant $(<5 \mathrm{~mm})$ was sieved to under $2 \mathrm{~mm}$ to meet the particle size requirements used by the mortar company. The particle size distribution curve is shown in Figure 3. 


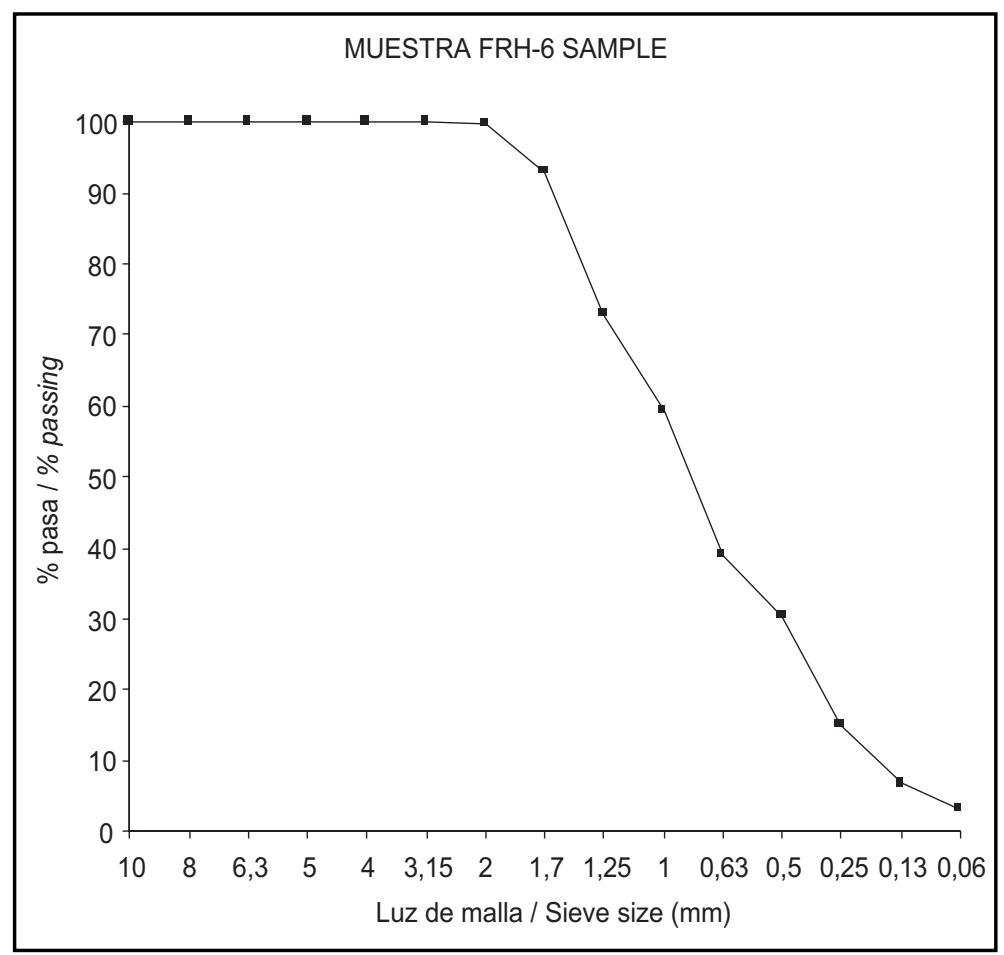

Figura 3. Curva granulométrica de árido reciclado FRH-6.

Figure 3. FRH-6 recycled aggregate size distribution curve.

Al objeto de simplificar los sistemas para poder deducir de forma más clara el efecto de la utilización de áridos reciclados de hormigón en las propiedades de los morteros, se realizaron las siguientes suposiciones de partida en el comienzo del diseño de las mezclas:

- Se estructuró el diseño de las mezclas en diferentes niveles, siendo el primero de ellos el estudio de las mezclas sin aditivos. En un segundo nivel, se consideró la utilización de los aditivos necesarios para que los nuevos morteros fabricados con arena reciclada fueran comparativamente similares a los morteros patrón fabricados con arena natural.

- Dada la amplia gama de tipos de morteros que pudieran existir dentro de cada clase, se seleccionó como patrón de referencia un mortero M5, según UNE-EN 998-2 (12), con arena caliza natural. Se seleccionó este tipo de mortero por ser de uso más generalizado. Asimismo, de utilizarse tipos de mortero con mayores resistencias, la incidencia de la utilización de arenas finas recicladas pudiera ser menos significativa.

- Las dosificaciones para cada uno de estos tipos de referencia se basaron en las formulaciones y experiencia previa por parte del equipo investigador.

\subsection{Durabilidad}

El estudio de durabilidad se centró en la determinación de la resistencia a la cristalización de sales, según la norma
The following initial assumptions were made in order to simplify the systems used and visualize more clearly the effect of the use of recycled concrete aggregate on mortar properties:

- Mix design was structured around different compositions. First, mixes were prepared without chemical additives. By contrast, the second group of mixes contained the admixtures necessary to ensure that the new recycled aggregate mortars would be comparatively similar to the natural sand mortars used as a control.

- Because of the wide range of types that might exist in each mortar class, an M5 mortar with natural limestone sand, as specified in UNE-EN 998-2 (12), was selected as the control. This type of mortar was chosen because of its widespread use. Furthermore, if higher strength mortars had been adopted for the trials, the impact of the use of recycled fines might have been less significant.

- The mix proportions designed for each of these controls were based on standard formulations and the research team's prior experience.

\subsection{Durability}

The durability study focused on determining resistance to salt crystallization, in accordance with Spanish 
UNE 12370. Esta norma es un método de ensayo para piedra natural, aplicado a probetas de mortero de $40 \mathrm{x}$ 40 x $160 \mathrm{~mm}$. Después de secar hasta masa constante, la probeta se sumerge en una solución de sulfato sódico, después se seca y se deja que se enfríe hasta temperatura ambiente. Este ciclo se repite 15 veces y se determina la variación de la masa (en porcentaje).

\section{RESULTADOS Y DISCUSIÓN}

\subsection{Caracterización de los áridos reciclados para morteros}

La Tabla 4 recoge los resultados de caracterización obtenidos para la muestra patrón de arena natural (FN) y las muestras de áridos reciclados de hormigón. standard UNE 12370. The test method described in the standard for natural stone was applied to 40 x $40 x$ 160-mm mortar prisms. After drying to constant mass, the prisms were immersed in a sodium sulphate solution, then dried and left to cool to ambient temperature. This cycle was repeated 15 times, and the percentage change in mass was determined.

\section{RESULTS AND DISCUSSION}

\subsection{Characterization of the recycled aggregate for mortars}

Table 4 gives the characterization data for the natural sand control (FN) and the recycled concrete aggregate samples.

Tabla 4 / Table 4

Resultados de caracterización de áridos reciclados finos para morteros. Characterization results of recycled fine aggregates for mortars.

\begin{tabular}{|c|c|c|c|c|c|c|c|}
\hline \multirow{2}{*}{ Característica / Characteristic } & \multicolumn{7}{|c|}{ Muestra / Sample } \\
\hline & $\mathbf{F N}$ & FRH-1 & FRH-2 & FRH-3 & FRH-4 & FRH-5 & FRH-6 \\
\hline Porcentaje de finos / Fine content (\%) & 11.14 & 2.66 & 3.47 & 3.26 & 6.71 & 5.12 & 6.40 \\
\hline Equivalente de arena / Sand equivalent (\%) & 76 & 71 & 74 & 69 & 67 & 73 & 45 \\
\hline Azul de metileno / Methylene blue test(gr/kg fracción 0,2 mm) & 0.25 & 0.25 & 0.25 & 0.25 & 0.50 & 0.25 & 0.5 \\
\hline Densidad real de la muestra seca / Dry simple real density $\left(\mathrm{g} / \mathrm{cm}^{3}\right)$ & 2.67 & 1.63 & 2.11 & 2.14 & 2.13 & 1.98 & 2.20 \\
\hline Absorción de agua / Water absorption (\%) & 0.34 & 7.60 & 8.09 & 6.73 & 7.84 & 6.65 & 7.18 \\
\hline Coeficiente de friabilidad / Friability (\%) & 22 & 26 & 25 & 34 & 23 & 26 & 23.9 \\
\hline Compuestos de azufre totales / Total sulphurs $\left(\% \mathrm{SO}_{3}\right)$ & $<0.20$ & 0.82 & 0.71 & 7.55 & 1.56 & 1.10 & 1.53 \\
\hline Sulfatos solubles en ácido / Acid soluble sulphates $\left(\% \mathrm{SO}_{3}\right)$ & $<0.10$ & 0.67 & 0.51 & 7.05 & 1.41 & 0.76 & 1.24 \\
\hline Cloruros solubles en agua / Water soluble chlorides $(\% \mathrm{Cl})$ & 0.0009 & 0.0035 & 0.0025 & 0.005 & 0.0037 & 0.0037 & 0.0056 \\
\hline
\end{tabular}

De acuerdo con los resultados obtenidos, el porcentaje de finos en los áridos reciclados es menor que en el árido fino natural (FN) usado como referencia. La densidad de la muestra seca es similar para todos los áridos reciclados y su valor está en todos los casos por debajo de la densidad del árido fino natural, lo que nos permite deducir que los morteros fabricados con estos áridos serán más ligeros que los morteros tradicionales. Este hecho podría ir en detrimento de sus prestaciones mecánicas. El coeficiente de absorción de agua es mucho mayor para los áridos reciclados, tal y como recogen otros autores $(3,9,13)$. Este parámetro tiene influencia sobre la trabajabilidad, así como en las prestaciones mecánicas de los morteros puesto que, al evaporarse el agua, pueden quedar huecos en el interior del material. Por este motivo, este parámetro es crítico y es necesario limitarlo estableciendo un porcentaje óptimo de mezcla de árido natural con árido reciclado. Dicho óptimo se establecerá tras analizar la influencia de cada porcentaje de sustitución en propiedades tales como la propia absorción del árido, la consistencia del mortero fresco y la resistencia mecánica a compresión del mortero endurecido. Los valores del coeficiente de friabilidad son
The results showed that the percentage of fines in the recycled aggregates was smaller than in the natural fine aggregate (FN) used as a control. The density values for the dry samples were similar for all the recycled aggregates, and consistently lower than the natural fine aggregate value. It may consequently be inferred that mortars manufactured with these aggregates would be lighter weight than traditional mortars, which could be detrimental to their mechanical performance. The water absorption coefficient was much higher for recycled aggregate, a finding that concurred with previous reports $(3,9,13)$. This parameter affects mortar workability and mechanical performance both, as the water may leave voids in the material when it evaporates. The value of this critical parameter must therefore be controlled by establishing an optimal natural/recycled aggregate mix ratio based on the effect of each replacement percentage on such properties as aggregate absorption, consistency of the fresh mortar and compressive strength of the hardened mortar. The friability index values were very similar to the findings for the natural aggregate, with the exception of sample $\mathrm{FRH}-3$, whose 
muy similares a los del árido natural, excepto para la muestra FRH-3 cuyo hormigón de partida parece presentar algún tipo de patología. Valores elevados de este parámetro se traducirán en un elevado desgaste del material. En el caso de los cloruros, en todos los casos nos encontramos por debajo del 0,06\%, límite más restrictivo establecido por la norma UNE-EN 998-2 para morteros que contienen refuerzos metálicos. Tanto para el valor del azufre total como para los sulfatos solubles en ácido, los valores obtenidos son muy similares en todos los casos, excepto en la muestra FRH-3, donde los valores obtenidos son muy superiores. En cualquier caso, el contenido de azufres totales es muy cercano al 1\% apuntado como límite en la norma UNE-EN 13139.

La influencia del porcentaje de sustitución en la absorción del mortero y en el contenido de azufres totales se ilustra en las Figuras 4 y 5 , respectivamente. Para original concrete seemed to be affected by some type of pathology. High values for this parameter mean a material with low wear resistance. In another vein, all the samples had chloride contents of under $0.06 \%$, the most demanding ceiling established in standard UNE-EN 998-2 for mortars with steel reinforcement. Total sulfur and acid-soluble sulfate values were very similar in all cases, except in the FRH-3 sample, which exhibited much higher values. In any case, the total sulfur content was very close to the $1 \%$ maximum specified in standard UNE-EN 13139.

The influence of the replacement percentage on mortar absorption and on total sulfur content is illustrated in Figures 4 and 5, respectively. When around $25 \%$ of the

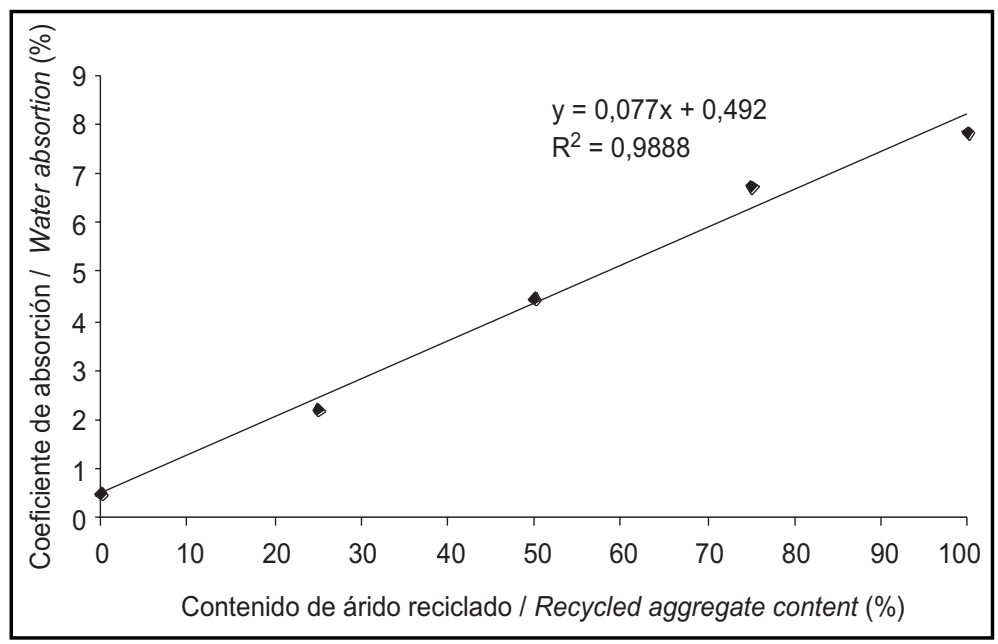

Figura 4. Variación de la absorción con el \% de árido reciclado. Figure 4. Absorption vs. recycled aggregate content.

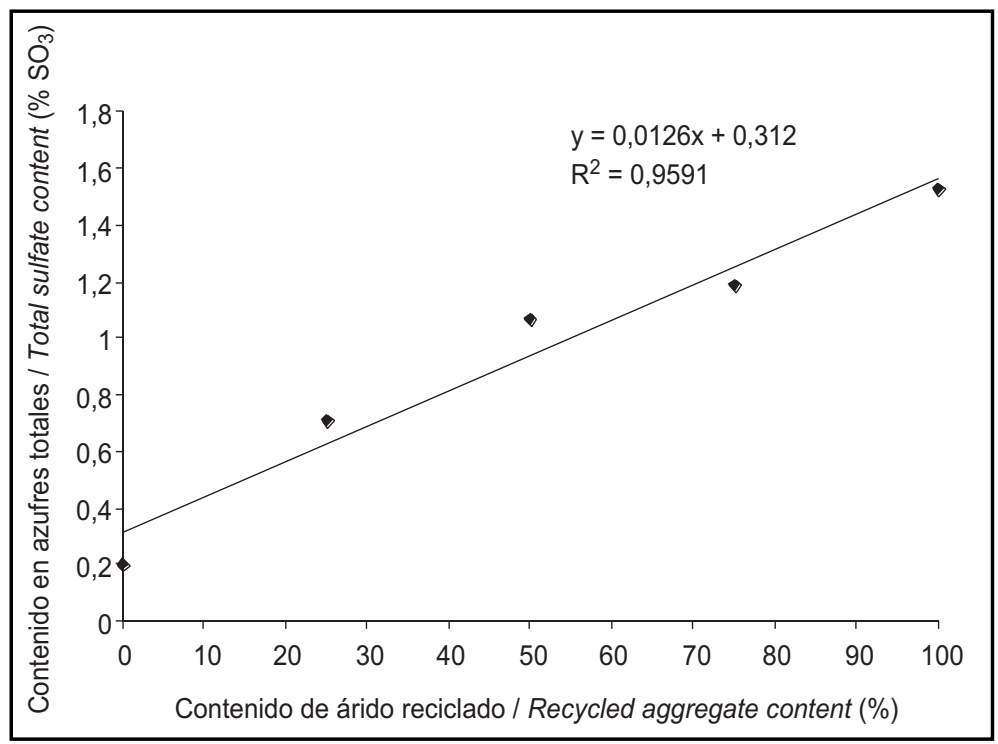

Figura 5. Variación del contenido de azufres totales con el \% de árido reciclado. Figure 5. Total sulphurs vs. recycled aggregate content. 
porcentajes de sustitución en torno al $25 \%$ de árido reciclado por árido natural, se observa que el contenido de azufres totales (expresado en $\%$ de $\mathrm{SO}_{3}$ ) se encuentra lo suficientemente por debajo del $1 \%$ establecido como límite en la norma.

Las fases minerales identificadas por DRX se recogen en la Tabla 5. La muestra de árido analizada está compuesta principalmente por calcita, que es característica del tipo de áridos utilizados en el ámbito geográfico donde se ha generado el escombro de hormigón. Otras fases como la etringita, el yeso o la portlandita están asociadas al cemento hidratado presente en el árido reciclado de hormigón. natural aggregate was replaced by recycled aggregate, the total sulfur content (expressed as a $\%$ of $\mathrm{SO}_{3}$ ) was acceptably lower than the $1 \%$ limit laid down in the standard.

The mineral phases identified using XRD are given in Table 5. The aggregate sample analyzed comprised primarily calcite, typical of the type of aggregate used in the geographic area where the concrete rubble was generated. Other phases, such as ettringite, gypsum or portlandite, were associated with the hydrated cement present in the recycled concrete aggregate.

Tabla 5 / Table 5

Mineralogía árido reciclado (FRH-6).

Recycled aggregate mineralogy (FRH-6).

\begin{tabular}{|c|c|}
\hline Fase mineral / Mineral phase & $\begin{array}{c}\text { Abundancia relativa del mineral / } \\
\text { Mineral relative abundance }\end{array}$ \\
\hline Calcita / Calcite $\left(\mathrm{CaCO}_{3}\right)$ & $\boldsymbol{\bullet \bullet \bullet \bullet}$ \\
\hline Cuarzo / Quartz $\left(\mathrm{SiO}_{2}\right)$ & $\boldsymbol{\bullet \bullet}$ \\
\hline Etringita / Ettringite $\left(\mathrm{Ca}_{6} \mathrm{Al}_{2}\left(\mathrm{SO}_{4}\right) 3(\mathrm{OH})_{12} * 26 \mathrm{H}_{2} \mathrm{O}\right)$ & $\boldsymbol{\bullet}$ \\
\hline Feldespato (plagioclasa) / Feldspar $(\mathrm{CaNa})(\mathrm{AlSi}) \mathrm{O}_{8}$ & $\boldsymbol{\bullet}$ \\
\hline Moscovita (arcilla) / Muscovite $\mathrm{KAl}_{2}\left(\mathrm{Si}{ }_{3} \mathrm{Al}\right) \mathrm{O}_{10}(\mathrm{OH})_{2}$ & $\boldsymbol{\bullet}$ \\
\hline Portlandita / Portlandite $\mathrm{Ca}(\mathrm{OH})_{2}$ & $\boldsymbol{\bullet}$ \\
\hline Yeso / Gypsum $\mathrm{CaSO}_{4} * 2 \mathrm{H}_{2} \mathrm{O}$ & $\boldsymbol{\bullet}$ \\
\hline
\end{tabular}

\subsection{Diseño de dosificaciones y caracterización de morteros con áridos reciclados}

Las dosificaciones ensayadas preliminarmente, dirigidas a determinar el óptimo de sustitución, se recogen en la Tabla 6. La sustitución de arena natural por arena reciclada es progresiva hasta llegar a la sustitución total en la muestra denominada como CO/100. El diseño de los morteros se realizó con contenidos de agua que aseguraran una consistencia similar en todos los casos. Los resultados de caracterización preliminar de los morteros se presentan en la Tabla 7 y en la Figura 6.

\subsection{Mix proportion design and characterization of recycled aggregate mortars}

The preliminary mix proportions tested to determine the optimal replacement percentage are given in Table 6. A total of seven replacement percentages were used, and the samples denominated accordingly, from C100/0 indicating 100 per cent natural sand, to $0 / 100$, to denote 100 per cent replacement. The mortars were designed with water contents that would ensure a similar consistency in all cases. The preliminary characterization results for the mortars are shown in Table 7 and Figure 6.

Tabla 6 / Table 6

Dosificaciones preliminares de morteros de cemento a ensayar. Preliminary mix proportions of cement mortars.

\begin{tabular}{|c|c|c|c|c|}
\hline $\begin{array}{c}\text { Tipo de mortero de cemento / } \\
\text { Mortar cement type }\end{array}$ & FN / FRH6 & $\begin{array}{c}\text { Cem } \\
\text { \% (peso / by weight) }\end{array}$ & $\begin{array}{c}\text { FN } \\
\text { \% (peso / by weight) }\end{array}$ & $\begin{array}{c}\text { FRH6 } \\
\text { \% (peso / by weight }\end{array}$ \\
\hline C100/0 & $100 / 0$ & 9 & 91 & 0 \\
\hline C90/10 & $90 / 10$ & 9 & 81.9 & 9.1 \\
\hline C80/20 & $80 / 20$ & 9 & 72.8 & 18.2 \\
\hline C75/25 & $75 / 25$ & 9 & 68.2 & 22.8 \\
\hline C50/50 & $50 / 50$ & 9 & 45.5 & 45.5 \\
\hline C25/75 & $25 / 75$ & 9 & 22.8 & 68.2 \\
\hline C0/100 & $0 / 100$ & 9 & 0 & 91 \\
\hline
\end{tabular}


Tabla 7 / Table 7

Características de los diferentes morteros de cemento ensayados. Characteristics of the different tested cement mortars.

\begin{tabular}{|c|c|c|c|c|c|c|c|c|}
\hline Tipo / Type & $\begin{array}{c}{ }^{1} \mathrm{H}_{2} \mathbf{O} \\
(\mathrm{g})\end{array}$ & $\begin{array}{l}\text { Consistencia / } \\
\text { Consistency } \\
(\mathbf{m m})\end{array}$ & $\begin{array}{c}\text { Densidad fresco / } \\
\text { wet density } \\
\left(\mathrm{g} / \mathrm{cm}^{3}\right)\end{array}$ & $\begin{array}{c}2 \mathrm{F7} \\
(\mathrm{MPa})\end{array}$ & $\begin{array}{c}{ }^{2 C 7} \\
(\mathrm{MPa})\end{array}$ & $\begin{array}{c}2 \mathrm{~F} 28 \\
(\mathrm{MPa})\end{array}$ & $\begin{array}{c}{ }^{2} \mathrm{C28} \\
(\mathrm{MPa})\end{array}$ & $\begin{array}{c}\text { Densidad endurecido / } \\
\text { Dry density } \\
\left(\mathbf{g} / \mathrm{cm}^{3}\right)\end{array}$ \\
\hline $\mathrm{C} 100 / 0$ & 13.5 & 181 & 2.2129 & & 8.28 & 3.6 & 13.92 & 2.017 \\
\hline $\mathrm{C} 90 / 10$ & 14.0 & 177 & 2.1502 & 1.61 & 6.03 & 3.09 & 11.21 & 1.966 \\
\hline C80/20 & 14.75 & 180 & 2.1071 & 1.61 & 5.37 & 2.55 & 9.24 & 1.919 \\
\hline $\mathrm{C} 75 / 25$ & 15.0 & 179 & 2.0915 & 1.40 & 4.93 & 2.53 & 9.17 & 1.885 \\
\hline C50/50 & 17.5 & 182 & 1.9232 & 0.83 & 2.58 & 1.44 & 5.11 & 1.726 \\
\hline $\mathrm{C} 25 / 75$ & 21 & 178.5 & 1.8354 & 0.51 & 1.53 & 0.92 & 3.10 & 1.590 \\
\hline $\mathrm{C} 0 / 100$ & 22.5 & 173 & 1.7131 & 0.40 & 1.10 & 0.64 & 2.13 & 1.462 \\
\hline
\end{tabular}

1 Contenido de agua / Water content.

2 Resistencias a 7 y 28 días / Strength at 7 and 28 days: Compressión (C) and Flexural (F).

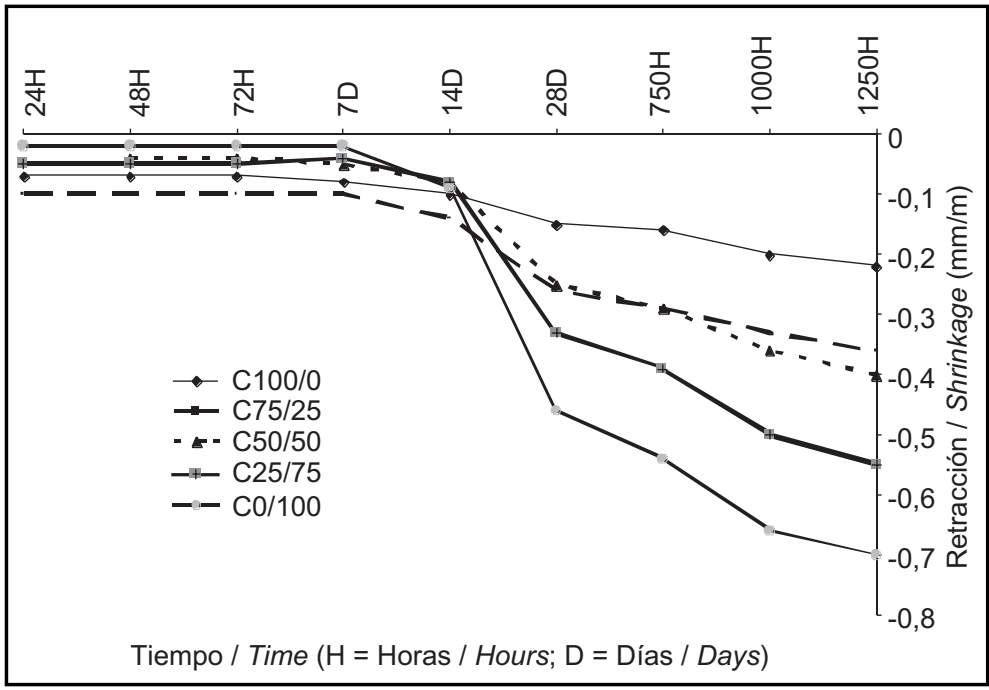

Figura 6. Retracción de los diferentes morteros de cemento. Figure 6. Shrinkage of mortars.

Se observa que la incorporación de árido reciclado aumenta la demanda de agua para unas consistencias similares de trabajo. Esto es debido a la mayor absorción de agua que presentan las partículas de árido reciclado frente a la de árido natural. No es aconsejable que el contenido de agua sea muy alto por las mayores retracciones de secado, que pueden provocar la aparición de grietas y fisuras. Este efecto es visible en la Figura 6 donde la retracción varía desde valores, a 1.250 horas, de $0,22 \mathrm{~mm} / \mathrm{m}$ de retracción en el mortero patrón (C100/0), a 0,7 mm/m de retracción en mortero con $100 \%$ de árido reciclado $(\mathrm{CO} / 100)$. Tendencias similares son apuntadas por Mesbah et al. (6). Asimismo, se observa una disminución en las densidades a medida que se incrementa la relación de sustitución de arena natural por arena reciclada. Este fenómeno obedece a una menor densidad de la propia arena reciclada frente a la natural.

Con relación a las resistencias mecánicas, la caída en valores obtenidos es considerable según aumenta la
The higher the percentage of recycled aggregate, the more water was observed to be needed to maintain similar working consistencies. This was because the recycled aggregate particles absorbed more water than the natural aggregate. Water content should not be very high because the increased drying shrinkage may cause cracking and fissuring. This effect is visible in Figure 6, where shrinkage at 1250 hours ranged from $0.22 \mathrm{~mm} / \mathrm{m}$ in the control mortar (C100/0) to $0.7 \mathrm{~mm} / \mathrm{m}$ in the $100 \%$ recycled aggregate mortar (CO/100). Comparable patterns were reported by Mesbah et al (6). Similarly, density was observed to decline with increasing ratios of recycled to natural sand, due to the lower density of the recycled sand itself compared to the natural sand.

Mechanical strength values, in turn, declined substantially with rising proportions of recycled 
proporción de árido reciclado. Una disminución muy alta conllevaría el encarecimiento del mortero por la necesidad de una sobredosificación de cemento para llegar a las resistencias mínimas exigidas en la EN 998-2. Sobre la base de los resultados obtenidos para los morteros de albañilería base cemento, se selecciona un máximo de sustitución de un $25 \%$ como máximo. A partir de dicho porcentaje de sustitución, se penaliza considerablemente la pérdida de resistencias. Para compensar dicha pérdida sería necesario una mayor cantidad de cemento, lo que encarecería considerablemente el precio del producto final. El porcentaje de sustitución es ligeramente superior al $20 \%$ establecido para la fracción gruesa en hormigón estructural (2).

Una vez establecido el $25 \%$ como porcentaje máximo admisible, se procedió a optimizar la dosificación con la utilización de aditivos (series C75/25 F1 a F4 de la Tabla 8), así como a completar la caracterización del nuevo mortero, tanto en estado fresco como endurecido. Se partió, como dosificación patrón, de un mortero de resistencia M5. Se analizaron parte de las propiedades de este mortero de referencia en fresco y endurecido $y$, a partir de ahí, se optimizó la utilización de aditivos en la fórmula con un $25 \%$ de sustitución de arena natural por reciclada. Los resultados de estas pruebas se recogen en la Tabla 8 . La diferencia de aditivos entre el mortero comercial y el mortero de arena reciclada obedece a lo siguiente: el árido natural es más compacto, tiene una menor absorción de agua y es menos poroso. Se añade una pequeña cantidad aggregate. A very steep decline would result in the need for a higher proportion of cement to reach the minimum strength requirements established in EN 998-2, and with it, higher costs. Further to the findings for cement-based masonry mortars, 25\% was chosen as the maximum replacement percentage. Higher replacement percentages led to substantially lower strength values. The higher cement content needed to offset this decline would raise the price of the end product considerably. The $25 \%$ replacement percentage is only slightly higher than the $20 \%$ ceiling established for the coarse fraction in structural concrete (2).

Having established the above maximum allowable percentage, mix proportions were optimized with the use of admixtures (C75/25 series F1 to F4 in Table 8) and the new mortar was characterized, both when fresh and after hardening. The mix proportion for an M5 strength mortar was used as the control. Both the fresh and hardened properties of this control mortar were analyzed and admixtures were then used to optimize the formula when recycled sand replaced $25 \%$ of the natural sand. The results of these tests are given in Table 8. Different admixtures were used for the commercial mortar and the recycled sand mortar because the natural aggregate was more compact, absorbed less water and was less porous. A small amount of an air-entraining agent was added to increase mortar workability. For the recycled aggregate

Tabla 8 / Table 8

Estudio de dosificaciones.

Study of mix proportions.

\begin{tabular}{|c|c|c|c|c|c|c|}
\hline \multirow{2}{*}{ Materiales aditivos / Materials additives } & \multicolumn{6}{|c|}{ Morteros / Mortars } \\
\hline & 2000-M5 & C75/25 & C75/25 F1 & C75/25 F2 & C75/25 F3 & C75/25 F4 \\
\hline CEM II-B-M 42.5R ( $\mathrm{gr} / \mathrm{kg})$ & 90 & 90 & 90 & 90 & 90 & 90 \\
\hline Arena caliza / Limestone sand (gr/kg) & 910 & 682.5 & 682.5 & 682.5 & 682.5 & 682.5 \\
\hline Árido reciclado FRH6 / Recycled aggregate (gr/kg) & - & 227.5 & 227.5 & 227.5 & 227.5 & 227.5 \\
\hline Retenedor de agua / Water keeper ( $\mathrm{gr} / \mathrm{kg})$ & 0.20 & - & 0.20 & 0.20 & 0.20 & 0.15 \\
\hline Aireante / airer (gr/kg) & 0.15 & - & - & - & - & - \\
\hline Aireante-plastificante / Airer-plasticizer (gr/kg) & - & - & - & 0.50 & 0.75 & 1.0 \\
\hline \multicolumn{7}{|c|}{ Caracterización / Characterization } \\
\hline Contenido en agua / Water content (\%) & 13.30 & 15.00 & 15.00 & 14.00 & 13.50 & 13.50 \\
\hline Consistencia / Consistency (mm) & 174 & 179 & 178 & 174 & 168 & 171 \\
\hline Densidad en fresco / Wet density $(\mathrm{kg} / \mathrm{l})$ & 1.98 & 2.09 & 1.96 & 1.99 & 2.00 & 1.95 \\
\hline Aire ocluido / Trapped air (\%) & 12.1 & 12.5 & 12.0 & 12.4 & 12.3 & 12.3 \\
\hline Retención de agua / Water retention (\%) & 87.87 & 85.40 & 89.29 & 89.89 & 90.50 & 86.52 \\
\hline 1 F7 (MPa) & 1.37 & 1.40 & 1.63 & 1.77 & 1.97 & 1.96 \\
\hline${ }^{1} \mathrm{C} 7(\mathrm{MPa})$ & 4.07 & 4.93 & 5.37 & 6.30 & 6.76 & 6.45 \\
\hline 1 F28 (MPa) & 2.36 & 2.53 & 3.00 & 3.42 & 3.66 & 3.55 \\
\hline${ }^{1} \mathrm{C} 28(\mathrm{MPa})$ & 7.55 & 9.17 & 10.03 & 12.01 & 12.65 & 12.20 \\
\hline Densidad endurecido / Dry density (kg/l) & 1.82 & 1.88 & 1.79 & 1.84 & 1.86 & 1.86 \\
\hline Retracción a 28 días / Shrinkage at 28 days $(\mathrm{mm} / \mathrm{m})$ & 0.445 & 0.520 & 0.556 & 0.594 & 0.675 & 0.709 \\
\hline
\end{tabular}

1 Resistencia a 7 y 28 días: Compresión (C) y Flexión (F) / Strength at 7 and 28 days: Compression (C) and Flexural (F). 
de un agente aireante para dar trabajabilidad al mortero. En el caso de morteros con áridos reciclados se utilizó un aditivo que combinaba la acción aireante con una acción plastificante (reductora de agua) para poder controlar la excesiva demanda de agua que presentan estas arenas.

La retención de agua en la formulación C75/25 (mortero sin aditivos con $25 \%$ de áridos reciclados de hormigón) debe ser mejorada puesto que es sensiblemente inferior a la retención del mortero comercial patrón M5. Una dosificación de derivado celulósico del 0,2\% mejora el valor de retención, incluso ligeramente por encima del patrón. La retracción a 28 días, medida sobre probetas de $4 \times 4 \times 16 \mathrm{~cm}$, es ligeramente superior en las formulaciones con áridos reciclados, aumentando a medida que se incrementa el porcentaje de aditivos. El resto de propiedades no evidencian diferencias significativas. La dosificación C75/25 F1 proporciona prestaciones muy similares a las del mortero patrón comercial M5. El mortero C75/25 F1 se selecciona para completar la caracterización (media de 3 valores) de todas las propiedades del mortero fresco y endurecido recogidas en la Tabla 9. mortars, an admixture was used that combined this airentraining action with a plasticizing (water-reducing) effect to control the high water content needed with this type of sand.

Water retention in the C75/25 formulation (mortar with no admixtures and $25 \%$ recycled concrete aggregate) required improvement, as it retained significantly less than the commercial M5 control. Adding a $0.2 \%$ dose of cellulose derivative raised retention to a level somewhat higher than found for the control. Twenty eight-day shrinkage, measured on $4 \times 4 \times 16 \mathrm{~cm}$ prisms, was slightly higher in the formulations with recycled aggregates, and grew with the percentage of admixture. No significant differences were observed in the remaining properties. Mix C75/25 F1 performance was very similar to the results observed for the commercial M5 control mortar. This mortar was chosen for characterization (average of three values) of all of the fresh and hardened properties shown in Table 9.

Tabla 9 / Table 9

Caracterización de morteros M5 y C75/25 F1.

Characterization of M5 and C75/25 F1 mortars.

\begin{tabular}{|c|c|c|c|}
\hline \multirow[b]{2}{*}{ Características / Characteristics } & \multirow[b]{2}{*}{ Norma / Standard } & \multicolumn{2}{|c|}{ Tipo de mortero / Mortar type } \\
\hline & & $\begin{array}{c}\text { Mortero patrón M5 / } \\
\text { Mortar M5 }\end{array}$ & \begin{tabular}{|c|} 
Mortero con $25 \%$ \\
de árido reciclado \\
C75/25 F1 / \\
Mortar containing $25 \%$ \\
recycled aggregate \\
\end{tabular} \\
\hline Consistencia / Consistency (mm) & UNE-EN 1015-3 & 174 & 178 \\
\hline Aire ocluido / Intruded Air voids (\%) & UNE-EN 1015-7 & 12,1 & 12.0 \\
\hline Densidad en fresco / Wet density $\left(\mathrm{gr} / \mathrm{cm}^{3}\right)$ & UNE-EN 1015-6 & 1.98 & 1.96 \\
\hline Retención de agua / Water retention (\%) & UNE-EN 1347 & 87.87 & 89.29 \\
\hline Resistencia a flexión, 7 días / Flexural strength, 7 days ( $\left.\mathrm{N} / \mathrm{mm}^{2}\right)$ & UNE-EN 1015-11 & 1.37 & 1.63 \\
\hline $\begin{array}{l}\text { Resistencia a compresión } 7 \text { días / Compression strength, } 7 \text { days } \\
\qquad\left(\mathrm{N} / \mathrm{mm}^{2}\right)\end{array}$ & UNE-EN 1015-11 & 4.07 & 5.37 \\
\hline Resistencia a flexión 28 días / Flexural strength, 28 days (N/mm²) & UNE-EN 1015-11 & 2.36 & 3.00 \\
\hline $\begin{array}{l}\text { Resistencia a compresión } 28 \text { días / Compression strength, } 28 \text { days } \\
\qquad\left(\mathrm{N} / \mathrm{mm}^{2}\right)\end{array}$ & UNE-EN 1015-11 & 7.55 & 10.03 \\
\hline Densidad en estado endurecido / Dry density $\left(\mathrm{gr} / \mathrm{cm}^{3}\right)$ & UNE-EN 1015-10 & 1.82 & 1.79 \\
\hline Permeabilidad al vapor de agua / Steam permeability $\left(\mathrm{kg} / \mathrm{m} * \mathrm{~s}^{*} \mathrm{~Pa}\right)$ & UNE-EN 1015-19 & $8.39 * 10^{-12}$ & $9.54 * 10-12$ \\
\hline $\begin{array}{l}\text { Coeficiente de absorción de agua por capilaridad / Water absorption by } \\
\text { capilarity }\left(\mathrm{kg} /\left(\mathrm{m}^{2 *} \mathrm{~min}^{0,5}\right)\right.\end{array}$ & UNE-EN 1015-18 & 0.585 & 0.739 \\
\hline $\begin{array}{l}\text { Módulo de deformación longitudinal / Longitudinal deformity modulus } \\
\qquad(\mathrm{MPa})\end{array}$ & UNE 83316 & 9941 & 10165 \\
\hline $\begin{array}{c}\text { Durabilidad (\% pérdida de peso tras } 15 \text { ciclos de exposición en una } \\
\text { solución de sulfato sódico) / Durability (\% of weight loss after } 15 \text { cycles } \\
\text { in a sodium sulfate dissolution) }\end{array}$ & UNE 12370 & 2.6 & 5.5 \\
\hline
\end{tabular}

El mortero C75/25 F1 manifiesta una ligera mejora de prestaciones mecánicas y de trabajabilidad con relación al mortero patrón M5. Dicha ganancia de resistencias está asociada a una mejor cohesión de la matriz del mortero con árido reciclado, tal y como se ilustra en las fotografías
According to these trials, mortar C75/25 F1 exhibited slightly better mechanical performance and workability than the M5 control. This increased strength was associated with the improved bonding of the matrix to the recycled aggregate, as observed in the scanning 
de microscopía electrónica de barrido (Figuras 7 y 8). Las propiedades hídricas no evidencian diferencias significativas. Sin embargo, el mortero C75/25 F1 tiende a ser ligeramente menos resistente al ataque externo de sulfatos. En cualquier caso, a tenor del estudio realizado, la elaboración de morteros comerciales con una sustitución parcial de un $25 \%$ (en peso) de árido reciclado de hormigón por arena caliza natural resulta ser técnicamente viable. En próximas contribuciones se abordarán otros aspectos de la investigación, como la influencia del árido reciclado en morteros base cal, la evaluación medioambiental y aspectos de viabilidad económica.

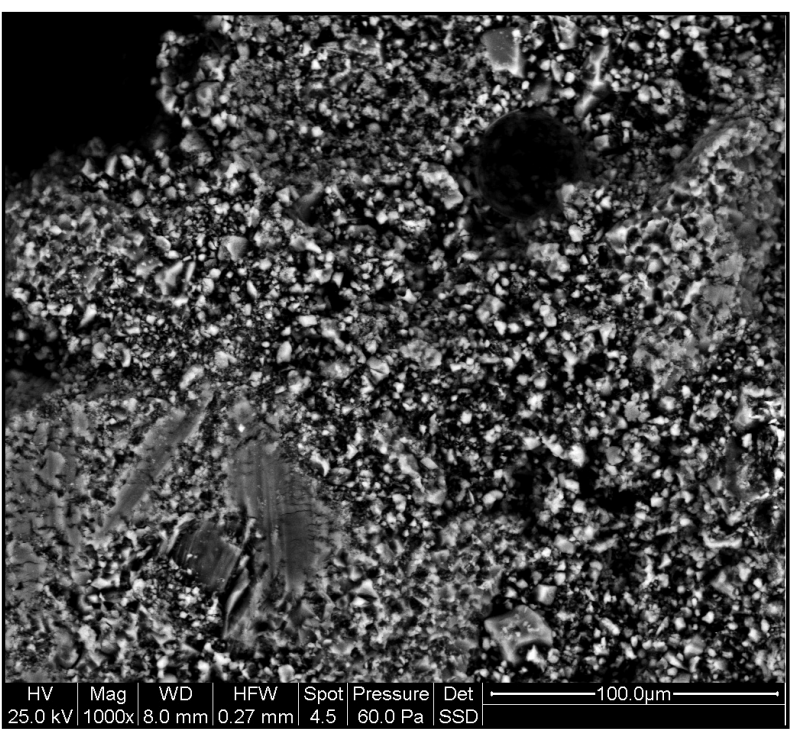

Figura 7. Detalle de la matriz cementante en el mortero M5. Figure 7. Detail of the cement matrix of M5 mortar.

\section{CONCLUSIONES}

Las principales conclusiones derivadas del presente estudio se exponen a continuación:

- Las características críticas de los áridos reciclados de hormigón para su utilización en la fabricación de morteros de albañilería son la absorción y el contenido en compuestos de azufre.

- Los morteros de albañilería base cemento pueden incorporar un $25 \%$ como máximo de árido reciclado, sin evidenciar pérdidas significativas de prestaciones mecánicas, trabajabilidad y retracción.

- La formulación de mortero base cemento con un $25 \%$ de sustitución de arena natural por reciclada, no requiere de nuevos aditivos ni de una mayor dosificación de los aditivos habituales.

- Los resultados obtenidos en los ensayos realizados al mortero aditivado con arena reciclada y al mortero comercial con arena natural, evidencian que no hay electron microscope photos (Figures 7 and 8). No significant differences were observed in moisture properties. Mortar C75/25 F1 tended to be slightly less resistant to external sulfate attack, however. In any event, the present findings are indicative of the feasibility of the manufacture of commercial mortars in which recycled concrete aggregate replaces 25\% (by weight) of the natural limestone sand. Future papers will deal with other aspects of the study, such as the effect of recycled aggregate on lime-based mortars, environmental assessment and economic feasibility issues.

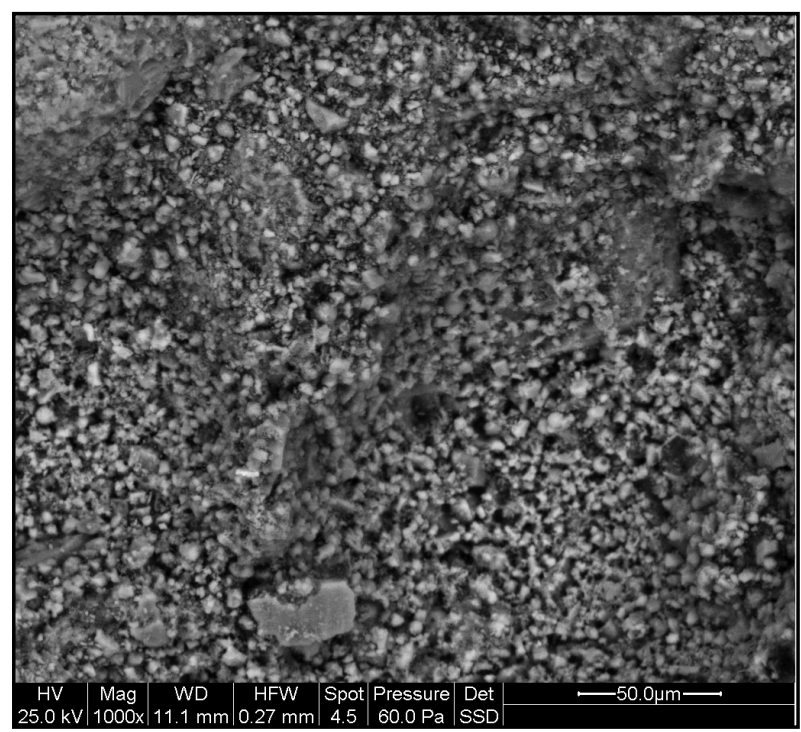

Figura 8. Detalle de la matriz cementante en el mortero C75/25 F1.

Figure 8. Detail of the cement matrix of C75/25 F1 mortar.

\section{CONCLUSIONS}

The main conclusions to be drawn from this study are listed below:

- The critical characteristics of recycled concrete aggregates for being used in the manufacture of masonry mortars are their absorption and sulfur compound content.

- Cement-based masonry mortars may contain up to $25 \%$ recycled aggregate with no significant detriment to their performance in terms of mechanical strength, workability or shrinkage.

- Cement-based mortar in which $25 \%$ of the natural sand is replaced with recycled aggregate calls for no new admixtures or larger proportions of standard admixtures.

- The results of the tests conducted on the mortars containing recycled and natural sand showed no significant differences in any of the properties studied. 
diferencias significativas en cuanto a las prestaciones analizadas. La mayor diferencia se relaciona con la absorción de agua, que resulta de importancia en el caso de utilización en exteriores de estos morteros. Incluso las resistencias mecánicas del mortero con arena reciclada son algo superiores al mortero patrón.

\section{AGRADECIMIENTOS}

Los autores del presente trabajo quieren agradecer al Ministerio de Medio Ambiente y al Departamento de Industria, Comercio y Turismo del Gobierno Vasco, por la subvención recibida para la realización del presente trabajo de investigación.
The most relevant difference was related to water absorption, which is important for mortars used on exteriors. The mechanical strength value found for the recycled sand mortar proved to be somewhat higher than for the control mortar.

\section{BIBLIOGRAFÍA / BIBLIOGRAPHY}

(1) Poon, C. S.; Kou, S. C.; Lam, L.: "Use of recycled aggregates in molded concrete bricks and blocks", Construction and Building Materials, 16 (2002), pp. 281-289. doi:10.1016/S0950-0618(02)00019-3

(2) Monografía M-11-ACHE: "Utilización de árido reciclado para la fabricación de hormigón estructural", p. 15, ACHE, 2006.

(3) Sánchez de Juan, M.; Alaejos, P.: "Influence of recycled aggregate quality on concrete properties", Proceedings (PRO 40) of International RILEM, conference on the use of recycled materials in building and structures, vol. 1 (2004), pp. 545-553.

(4) Winkler, A.; Müeller, A.: "Recycling of fine processed building rubble materials", Use of Recycled Concrete Aggregate, pp. 157-168, Thomas Telford Publishing, London, 1998.

(5) Sánchez de Rojas, M. I.; Marín, F. P.; Frías, M. and Rivera, J.: "Viability of utilization of waste from ceramic products in precast concretes", Mater. Construcc., 51 (263-264) (2001), pp. 149-161.

(6) Mesbah, H. A.; Buyle-Bodin, F.: "Efficiency of polypropylene and metallic fibres on control of shrinkage and cracking of recycled aggregate mortars", Construction and Building Materials, 13 (1999), pp. 439-447. doi:10.1016/S0950-0618(99)00047-1

(7) Corinaldesi, L. F. R.; Giuggiolini, M.; Moriconi, G.: "Use of rubble from building demolition in mortars", Waste Management, 22 (2002), pp. 893-899. doi:10.1016/S0956-053X(02)00087-9 PMid:12423051

(8) Miranda, L. F. R.; Selmo, S. M. S.: "Construction and demolition waste variability and its influence on mansory and plastering mortars properties", Proceedings of WASCON 2003 (2003), pp. 241-250.

(9) Miranda, L. F. R.; Selmo, S. M. S.: "CDW recycled aggregate renderings: Part I - Analysis of the effect of materials finer than $75 \mu \mathrm{m}$ on mortar properties", Construction and Building Materials, 20 (2006), pp. 615-624. doi:10.1016/j.conbuildmat.2005.02.025

(10) Miranda, L. F. R.; Selmo, S. M. S.: "CDW recycled aggregate renderings: Part II - Analysis of the effect of materials finer than 75 $\mu \mathrm{m}$ under accelerated aging performance", Construction and Building Materials, 20 (2006), pp. 625-633. doi:10.1016/j.conbuildmat.2005.02.026

(11) UNE-EN 1313: Áridos para morteros, 2003.

(12) UNE EN 998-2: Especificaciones de los morteros para albañilería. Parte 2: morteros para albañilería, 2004.

(13) Rolón Aguilar, J. C.; Mendoza, D. N.; Huete Fuentes, R.; Blandón González, B.; Terán Gilmore, A.: "Characterization of concrete made with recycled agregate from concrete demolition waste ", Mater. Construcc., 57 (2007), pp. 5-15. 